\title{
Observations on Medically Important Arthropods in Brazil ${ }^{1}$ Algumas Considerações sobre Artrópodes de Interesse Clínico no Brasil
}

\author{
Philip D. Marsden²
}

MARSDEN, P. D. Observations on Medically Important Arthropods in Brazil. Cad. Saúde Públ., Rio de Janeiro, 9 (4): 508-513, Oct/Dec, 1993.

A brief review of some medically important arthropods in Brazil is presented. It is sufficient to show that we must expand our training of biologists in this field if endemic diseases are to be controlled in the next decade.

Key words: Arthropods; Medical Importance; Endemic Disease Control; Human Resources

\section{SKIN PARASITES}

Since Sarcoptes scabei var. homnis is still responsible for the most common skin disease of the Brazilian interior, it deserves priority. Resistance to benzyl benzoate is still not confirmed. The instructions for use is sufficiently complex to merit a written insertion in the packet. Clothes should be discarded and boiled, and the patient given a thorough bath and shampoo. The scabicide should be applied to all exposed skin with the exception of the eyelids, washed clothes donned, and no bath taken for 48 hours to kill emergent larval mites. All family members should be treated at the same time. The regimen can be repeated if necessary. Failure is due to improper application and not resistance. Scabies clinics were set up in London in 1940 during World War II. Mellanby (1944), in his pioneering experiments, showed that female mite resident populations are rapidly reduced by literally scratching the roof from over their heads due to sensitization of the skin from acarine products. Neither sarcoptic mange or

\footnotetext{
${ }^{1}$ Paper given at the International Conference on Health, Environment and Development (CIMADES), 20-24/04/92, Fundação Oswaldo Cruz, Rio de Janeiro, Brasil.

${ }^{2}$ Núcleo de Medicina Tropical e Nutrição da Universidade de Brasília. Caixa Postal 4671, Brasília, DF, 70919-970, Brasil.
}

demodectic mange of animals can cause more than transient irritation, since such mites are very host specific and do not multiply in man. Norwegian scabies, where the skin is honeycombed by thousands of mites, is a rare syndrome first described in Norwegian lepers in 1842 . I have seen it in many conditions with sensory loss or loss of immune function, including AIDS. There is a shortage of scabicides in my field clinics at the moment. Gamma BHC can be used but can only be left on the skin for 12 hours, due to percutaneous absorption. For any irritant rash, scabies must be considered, as it is very pleomorphic. In infected bacterial forms it is usually pointless to try to find a female in a burrow. Dust mites such as Dermatophagoides are responsible for most childhood asthma where they have been investigated and are almost impossible to eradicate from the home.

Yersina pestis var. orientalis escaped from China in the $19^{\text {th }}$ century and was established by flea/rat-infested shipping in wild rodents in East Africa and South and North America. It is mainly a problem in the north of Bahia, Ceará and Pernambuco. The WHO reference laboratory is in Recife, and the yearly number of cases is small due to an efficient surveillance service. Tungiasis due to the highly modified Tunga penetrans is another disease caused by Siphonoptera. Of South American origin, it passed to Africa in the sand ballast of slave ships and rapidly spread 
throughout that continent. Associated with poor domestic hygiene, pigs, and bare feet, it can be a serious problem in sick people lying on hut floors. It can predispose to clostridial infection such as tetanus or gas gangrene. There was a small epidemic of murine fleaborne typhus reported from Santarém in this last decade.

Only head lice (Pediculus humanus captis) are common in Brazilian children. Pediculus humanus corporis, the vector of Rickettsia prowazeki is virtually restricted to Andean areas because Brazilians use light clothing and are generally clean. Tick-transmitted Rickettsia rickettsia is well documented in São Paulo, which is where one should look for Borrelia burgsdorferi transmission in a deer-infested area. Using specific probes we found no evidence of Lyme disease recently in ticks of the central plateau, but failed to capture implicated ticks (eg. Ixodes dammini). The situation of argasid-transmitted Borrelia in Brazil deserves investigation, since $B$. venezuelensis, $B$. mazzottii and $B$. turicata can cause relapsing fever. I know of no record of human babesiosis from Brazil. Vagabond's disease due to ecotoparasites was once common in England (a skin lichenification due to ectoparasites plus failure to wash). I have seen Pthirus pubis on the eyelashes of two Englishmen.

\section{HEMIPTERA}

Brumpt in the 1920's showed that cimex will incubate Trypanosoma cruzi. In fact, $T$. cruzi grows in a wide variety of arthropods. The question of whether bed bugs or fleas are capable of transmitting $T$. cruzi to man merits attention, since large domestic populations of these insects can develop after a Chagas' disease control programme.

We are still in the surveillance phase of the national control programme for Chagas' disease, and as our pilot area of Mambaí enters its $12^{\text {th }}$ year it appears that communitybased surveillance is growing in importance over time (Garcia-Zapata et al., 1988). Of the control programme reported in the literature, the surveillance phase has always been the most difficult to execute. Our techniques in Mambaí continue to function well because of their simplicity. Even the PIATS (Postos de Informação e Ataque Triatomíneo) continue to turn in satisfactory results and accurate costs have been made by my colleague, Dr. M. T. Garcia-Zapata. However, in both neighbouring municipalities there are reports of Triatoma infestans recovery, and since we believe this vector mainly travels with visitors it is perhaps not surprising. Of the 12 species of triatomine captured to date, 4 have the potential to replace $T$. infestans and reestablish human transmission of $T$. cruzi . They are listed below with comments on their control risk.

1. Triatoma sordida - from the beginning of our studies on the domestic ecology of triatomines in Mambaí this has been a common species in chicken coops, with an increasing tendency to invade households. It has been captured in the virgin cerrado and clearing of this to make cattle farms may force it into houses. Since it shows an apparent preference for chicken blood this must explain its very low T. cruzi infection rate $(<1 \%)$. In Mambaí it is a low risk vector, in spite of house colonization, although SUCAM (Superintendência de Campanhas de Saúde Pública) persists in residual spraying.

2. Rhodnius neglectus - is in about every second palm tree, frequently in animal nests where it shows a relatively high infection rate with T. cruzi, but rarely colonizes houses. The great majority captured in houses are flying adults.

3. Triatoma pseudomaculata - a wide valency bug, but in our limited survey area we have seen one colony established in a corn bin.

4. Panstrongylus megistus - the situation here is of great interest, since it was recorded as the predominant triatomine in houses in the region in the 1950's, but appears to have been completely displaced by $\mathrm{T}$. infestans in households by the time we started our 
studies. Over 17 years we have caught less than a dozen adults, the majority heavily infected with T. cruzi. We imagine Didelphis nests to be their origin based on the work in São Paulo and Bambuí, but this is unproven.

We have a hotchpotch of further species, but they have no potential importance as house invaders. We have described in several papers the behavior of $T$. costalimai, which is mainly restricted to rock piles feeding on lizards. Both it and P. diasi fly into houses occasionally at night. There is only one record of $T$. williamsi from the area.

I am aware that there are many different aspects of bug behavior recorded, including Central and South America, which we do not see or have not investigated sufficiently. I list a few: 1) Attraction to light, eg, P. megistus seems to be attracted in some areas and not others; 2) Factors determining active and passive bug migration, especially of important vectors. It is essential to have such information during the surveillance phase; 3 ) Triatomine reinvasion of houses and the whole of hygiene, domestic animals and wall ecology as determinant factors; 4)

Dissemination of satisfactory surveillance techniques working nationally; 5) The suspicion of $R$. prolixus in Goiás is still not fully substantiated; 6) How successful are current control measures with pyrethroids of a species which normally resides in and out of the peridomicile, but is a relatively good vector, eg. T. braziliensis?

The improvement in insecticides for Chagas' disease control in the last decade has been noteworthy (Anonymous, 1988) and the pyrethroids have the advantage of better acceptabilitty by dwellers and long duration of action even on poor wall materials (unpublished data). Certainly the time has come to try and reach all affected areas using this control approach, although each country, in terms of population collaboration and the transmiting triatomine, will necessitate modifications in the spraying and surveillance programme.

The role of triatomines in xenodiagnosis is still important in isolating strains of $T$. cruzi in patients with chronic infections, in assessing chemotherapy, and in evaluating wild animal reservoirs. Yet only one Bahian strain has been assessed as regards its susceptibility to the most effective xenodiagnostic agent extant, namely Dipetalogaster maximus (Torno et al., 1981). To do such studies properly we must clone both triatomine and parasite.

\section{DIPTERA}

\section{Tsetse and Mosquitoes}

Now to the Formula I insects, the Diptera, the most sophisticated in terms of flight, behavior, and feeding. I commence with a picture of Formula IA - the tsetse - which led to enormous work in my old school so that at least African children could have milk. Actually, we tackled it the wrong way with big biology. As we know today, a French simple trap which can be made in the village and looks like a cow to the tsetse and the rearing of trypanosome resistant cattle is better. A tsetse has been found in the shales of Colorado so probably there was a Glossina in the New World, probably feeding on the extint Hippicus. A major problem with the tsetse is that it nurtures its larva with milk inside its own abdomen, so that there are no intermediate stages to attack.

Mosquitoes however have an aquatic intermediate stage, and increasing emphasis will be placed on attacking these (eg. Aedes aegypti in Rio de Janeiro). Television should be used more, but natural pathogens and artificial toxic agents in breeding sites have their place in certain situations. I think a major factor in the increase of Amazonian malaria is irresponsible garimpeiros (pan miners) creating surface breeding sites with no realization of their potential danger. Also chemoprophylaxis can be of use if correctly selected and applied, but specific treatement of malaria is a tragedy because of mefloquine abuse. Very little decent applied research is done on mosquitoes in Brazil, but from nearby Surinam comes a report of the efficacy of deltamethrin-impregnated bed nets in an area of Anopheles darlingi transmission, 
confirming numerous international reports with other species.

As recently emphasised, the idea of sitting back waiting for a vaccine is ridiculous when so much can be done in practical terms (Cox, 1991). I lament the passing of the old classical malariologist epitomized in this institution by L. M. Deane.

Several other anophelines apart from $A$. darling $i$ have been implicated in the transmission of Amazonian malaria, but it remains the main vector in Brazil. We regularly see in Brasília patients with severe falciparum malaria, and dissemination to other parts of this vast country is a constant danger. Small epidemics of vivax have been documented in this way in most South American countries and in the United States. To my mind, the greatest discovery ever made to benefit man's survival in warm climates was Müller's discovery of the residual insecticide effect of moth proofing woolens. He is one of the few Nobel Prize winners who had no formal paper submitted for consideration in Stockholm - just a section of his report to his drug company. Now, today what is the role of residual insecticide spraying in the control of Amazonian malaria? What insecticide should be used and when, especially in view of the emergence of behavioral resistance in $A$. darlingi?

What shoud be the official approach to larval combat and chemoprophylaxis?

Mosquitoes also transmit a whole variety of viruses that are pathogenic to man, but time only permits brief discussion of two that are very much in the news, namely the agents of yellow fever and dengue. Since most primates have antibodies to yellow fever transmitted by sylvatic vectors (eg. Haemagogus) it cannot be eradicated. Insect control must depend on preventing urban yellow fever, and this means control of A. aegypti. Not even the United States of America has managed to maintain this, and the difficulties in Brazil are well known to this group. A particular problem to my mind is the keen Brazilian enthusiasm for household foliage and plants stimulated quite rightly by such pioneers as Burle Marx. I fail to see why more television time is not used to help SUCAM in this difficult task. The majority of cariocas even in favelas would look for larvae and put oil (e.g. cooking oil) on vases or empty them if they were instructed. They must have a better idea of what they are up against! Outside a sophisticated community this approach is more difficult, but the success of our group in community surveillance for Chagas' disease shows that much can be done even by rural communities. Dengue is not only transmitted by this species, but unfortunately $A$.

albopictus breeding in old tires etc. A nice point is the extent to which you should use scarce public funds to avoid haemorrhagic dengue when you look at the results of the countrywide epidemic that occurred in Cuba and the actual number of cases of haemorrhagic dengue.

Culex species are the established vectors of Bancroftian filariasis in Brazil. Why this important helminth remains relatively restricted to a few coastal cities so long after slave introduction is strange (Recife, Belém, Salvador, Porto Alegre, Florianópolis). The commonest mosquito in Brasília is Culex cinquefasciatus, but to my knowledge we have never had a case although there is much FNS (Fundação Nacional de Saúde) technical time spent looking for breeding sites. The best treatment for such sites of static water is the use of inexpensive polystyrene beads which obstruct larval respiration.

\section{Phlebotomines}

Nobody seems to have asked why certain species seem to be such specific transmitters among the multitude of potential vectors. Perhaps this is more a shortage of skilled workers rather than real differences.

House spraying with residual insecticide is routine practice for kala azar outbreaks promoted by Lutzomyia longipalpis, but semms not to be appropriate in situations to combat transmission of mucocutaneous leishmaniasis. Tree trunk spraying for $L$. umbratilis seems a bit fanciful. We had no success with DDT peridomiciliary spraying 
for L. whitmani, our vector of Leishmania viannia brasiliensis in Três Braços, Bahia (França et al., 1991). In my view, current phlebotomine research is geared too much to taxonomy. For instance, we have 40-odd species in the forest in Três Braços, but only one peridomiciliary transmitter. Now what made L. whitmani adapt so successfully to cacao plantations? Forty kilometres away we have a similar situation with $L$. intermedia. I get the impression often from my patients that they have stepped into a hot focus of transmission. A microclimate around an animal burrow - but what animal for Leishmania viannia brasiliensis? Then is all this genitalia taxonomy really correct - there seem to be several types of whitmani like there are several types of $P$. megistus. Why don't the molecular taxonomists get more into this field?

At any rate, setting this all aside, therapy is the key to control from supervised centres. But current therapy is unscientific since pentavalent antimonials are unstable. A recent publication shows how much leishmaniasis is costing Brazil using this approach (Vieira et al., 1990). Fortunately there are some recent developments in drug therapy.

The Army is always worth watching in relation to such endemic disease problems, since they have a very practical approach. Leishmaniasis was significantly reduced in some Amazonian garrisons just by changing the hour of river bathing!

\section{Other Diptera}

We descend now to flies with non-syringelike mouth parts. The mess caused by Simulium bites is macroscopically visible, and this group are the vectors of onchocerciasis which fortunately for Brazil is restricted to an extension of the Venezuelan focus in Roraima. My experience of course is African. The exquisite sensitivity of Simulium larvae to less than one part per million of DDT was realized when a donkey with a load of DDT fell into a Kenyan river. Although other larvicides are now used in the very successful World Bank Programme in Africa, seeding headwaters will be difficult in such remote
Brazilian areas, especially if the river source is outside national teritory. No situation like Simulium naevi utilizing fresh water crabs as larval and pupal resting sites is described from the New World.

The role of simulidae in promoting Pemphigus foliaceus, suggested by epidemiological evidence many years ago, remains speculative, but it would seem that Simulium saliva is sufficiently toxogenic to initiate an autoimmune response to the intercellular epidermal substance. The fortunes of the specific hospitals for pemphigus tend to follow the opening of new rural areas. Simulium saliva deserves investigation in inbred mice susceptible to Pemphigus foliaceus autoantibodies. The haemorrhagic syndrome of Altamira which was also linked to simulidae has not been reported recently (Prata \& Marsden, 1977). Simulidae are responsible for Mansonella ozzardi transmission, in contrast to Trinidad where Culicoides sp. is the vector. In Africa, Culicoides sp. are also responsible for Mansonella perstans and Mansonella streptocerca transmission.

Culicoides has been implicated in short term viral infections of man in Amazonas by the Belém group (eg. Oropouche, Mayaro). As time runs out one is still left with a host of Diptera responsible for the various forms of myiasis. I can only comment on one form: furuncular myiasis. Cordylobia arthropophaga fortunately did not reach these shores from Africa because sailboats carrying slaves are slow, but I see no reason why it could not establish itself here. Furuncular myiasis is sufficiently dramatic to seek early medical care. Dermatobia hominis, the New World bot fly, is badly named since it is much more a problem of cattle. I see many more white cows now in Brazil because they develop much less berne (Marsden et al., 1979). But what was the original host of this cuterebrid and why does a cow never develop immunity?

Venomous arthropods must be left as I was asked to deal with vectors.

In closing one has to lament the limited opportunities available to biologists for developing a career in medical entomology. 


\section{RESUMO}

\section{MARSDEN, P. D. Algumas Considerações sobre Artrópodes de Interesse Clínico no Brasil. Cad. Saúde Públ., Rio de Janeiro, 9} (4): 508-513, out/dez, 1993.

$\mathrm{O}$ autor faz uma breve revisão de alguns artrópodes de interesse clínico no Brasil. É suficiente demonstrar que é necessário expandir os programas de capacitação de biólogos nesse campo para poder controlar as doenças endêmicas durante a próxima década.

Palavras-Chave: Artrópodes; Importância Clínica; Controle de Endemias; Recursos Humanos

\section{REFERENCES}

ANONYMOUS, 1988. Pyrethroid insecticides in public health. Parasitology Today, 4: 510-511.

COX, F. E. G., 1991.Malaria vaccines while we are waiting. Parasitology Today, 7: 189-190.

FRANÇA, F.; LAGO, E. L.; TADA, S.; COSTA, J. M. L.; VALE, K.; OLIVEIRA, J.; COSTA, M. A.; OSKAI, M.; CHEEVER, L.; NETTO, E. M.; BARRETO, A. C.; JOHNSON, W. D. \& MARSDEN, P. D., 1991. An outbreak of human Leishmania (viannia) braziliensis infection. Memórias do Instituto Oswaldo Cruz, 86: 169-174.
GARCIA-ZAPATA, M. T.; MARSDEN, P. D.; VIRGENS, D. \& SOARES, V. A., 1988. Epidemiological Vigilance with community participation in the control of vectors of Chagas' disease in Goiás, Central Brazil. Revista A rgentina de M icrobiologia, 20 (Supl.): 106-117.

MARSDEN, P. D.; SHELLEY, A. J. \& ARMITAGE, P., 1979. The number of Dermatobia hominis lesions in zebu cow hides of different colours. Transactions of the Royal Society of Tropical M edicine and Hygiene, 73: 458-459.

MELLANBY, K., 1944. Scabies Oxford War Manuals. London: Oxford University Press.

PRATA, A. \& MARSDEN, P. D., 1977. Infectious disease in Brazil today. Canadian Journal of Public Health, 68: 204-209.

TORNO, C. O.; SOARES, V.; CUBA, C. C.; BARRETO, A. C.; ALVARENGA, N. J. \& MARSDEN, P. D., 1981. A case of xenodiagnosis. Revista do Instituto M edicina Tropical de São Paulo, 23: 229-232.

VIEIRA, J. B.; LACERDA, M. M.; \& MARSDEN, P. D., 1990. National reporting of leishmaniasis. The Brazilian experience. Parasitology Today, 6: 339-340. 